Sains Malaysiana 50(5)(2021): 1357-1365

http://doi.org/10.17576/jsm-2021-5005-15

\title{
Views on Unassisted Childbirth among Mothers at a Teaching Hospital in Kuala Lumpur, Malaysia
}

(Pandangan Tentang Kelahiran Tanpa Bantuan dalam kalangan Ibu di Hospital Pengajar di Kuala Lumpur, Malaysia)

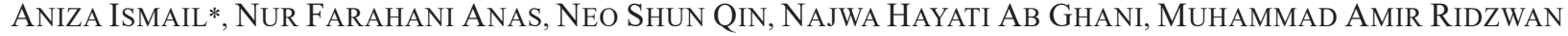

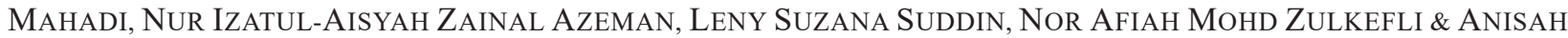 \\ BAHAROM
}

\section{ABSTRACT}

A cross-sectional study was conducted among mothers visiting clinic in UKMMC from 1st to 19 th August 2016 to acquire opinions on unassisted childbirth and the determinant factors among mothers at a teaching hospital. Structured questionnaires were used in assessing their opinions on unassisted childbirth. A total of 259 respondents were recruited, 229 of them who met the inclusion criteria were included for analysis. Majority (87.3\%) was Malay and 98.7\% of respondents were more than 25 years old. The prevalence for mothers who agreed with unassisted childbirth was $6.6 \%$. Bivariate analysis showed Malay $(p=0.013)$ and non-working mothers $(p=0.000)$ are the significant factors. There was no significant association between opinions on unassisted childbirth and quality of government healthcare services. Multivariate analysis showed middle income and non-working mothers were the significant factors contributing to opinions on unassisted childbirth. The outcome showed minority of mothers agreed with unassisted childbirth, middle income group and non-working mothers agreed on unassisted childbirth. Dissatisfaction to the quality of care at government healthcare services was not found to be the reason for unassisted childbirth. However, there could be other factors contributing to opinions on unassisted childbirth delivery which were not studied. Community-based study should be conducted to determine the other factors.

Keywords: Childbirth; government; mothers; teaching hospital

ABSTRAK

Suatu kajian keratan rentas telah dijalankan terhadap ibu yang melawat klinik antenatal di UKMMC dari 1 hingga 19 Ogos 2016 untuk mendapatkan pandangan terhadap kelahiran tanpa bantuan dan faktor yang mempengaruhinya dalam kalangan ibu di hospital pengajar. Borang soal selidik berstruktur telah digunakan untuk menilai pandangan mereka terhadap kelahiran tanpa bantuan. Sejumlah 259 responden telah direkrut dan seramai 229 yang memenuhi kriteria rangkuman telah diambil kira untuk dianalisa. Majoriti (87.3\%) adalah Melayu dan 98.7\% responden berusia 25 tahun ke atas. Prevalen ibu yang bersetuju dengan kelahiran tanpa bantuan adalah sebanyak $6.6 \%$. Analisis bivariat menunjukkan bahawa berbangsa Melayu ( $p=0.013)$ dan ibu yang tidak bekerja $(p=0.000)$ merupakan faktor yang signifikan. Tidak terdapat perkaitan yang signifikan antara pandangan terhadap kelahiran tanpa bantuan dengan kualiti perkhidmatan di pusat kesihatan kerajaan. Analisis multivariat menunjukkan bahawa pendapatan isi rumah sederhana dan ibu yang tidak bekerja adalah faktor signifikan yang menyumbang kepada pandangan terhadap kelahiran tanpa bantuan. Hasil kajian menunjukkan bahawa hanya minoriti ibu, pendapatan isi rumah sederhana dan ibu yang tidak bekerja bersetuju dengan kelahiran tanpa bantuan. Ketidakpuashatian terhadap kualiti perkhidmatan di pusat kesihatan kerajaan didapati bukan faktor penyumbang terhadap kelahiran tanpa bantuan. Walau bagaimanapun, kemungkinan juga terdapat faktor lain yang menyumbang kepada pandangan terhadap kelahiran tanpa bantuan yang tidak dikaji. Kajian berasaskan komuniti perlu dilakukan bagi menentukan faktor-faktor lain tersebut.

Kata kunci: Ibu; hospital pengajar; kelahiran; kerajaan 


\section{INTRODUCTION}

Normal childbirth could take place without unnecessary medical interventions for most pregnancies especially among healthy and low-risks mothers. However, the complications that might arise throughout the birth processes are absolutely unpredictable (Olsen \& Clausen 2012). In recent years, the rate of home birth has increased around the world (Aliyev et al. 2017). In the United States of America (USA), the number of out-of-hospital births have increased, in which it goes up from $1.26 \%$ in 2011 to $1.36 \%$ in 2012 and in overall two-thirds of USA populations $(66 \%)$ have practiced out-of-hospital births (Aliyev et al. 2017; MacDorman et al. 2014).

American College of Obstetrician and Gynaecology (ACOG 2011) has defined unassisted childbirth as the planned delivery typically using natural childbirth methods. Such delivery takes place in a non-clinical setting, preferably at home rather than in a hospital or a birth centre and accompanied by an expert midwife or lay attendant in dealing with home births. Meanwhile, in Malaysia, it is defined as a delivery in a clean and safe non-clinical setting attended by skilled birth attendants who have registered with the Ministry of Health $(\mathrm{MOH})$ (Family Health Development Division 2013).

The previous study has concluded that there was a three-fold increase in the neonatal mortality rate in association with less medical intervention during planned home births compared to a planned hospital birth (Wax et al. 2010). However, the randomized trials showed no strong evidence of differences to favour the low-risk pregnant women for both planned hospital birth and planned home birth (Wax et al. 2010).

In Malaysia, maternal mortality rate (MMR) has shown a declining pattern from 1950 to 2010 due to the implementation of several health programmes over this 60 years including the Maternal and Child Health programme (MCH) (Yadav 2012). Recently, revolution in the living style, education, internet surfing and experience has contributed in increasing trend of unassisted childbirth in Malaysia. Those who favoured unassisted childbirth build their own network to support this mode of delivery. The success rate of the program was based on the ideology obtained from internet sources in which might lead to an increasing pattern of MMR in future.

Thus, the objective of this study was to assess the opinions or views on unassisted childbirth (without assistance of medical personnel) among the mothers at a teaching hospital. Findings from this study will be able to assist and improve $\mathrm{MCH}$ related healthcare system in Malaysia.

\section{Materials AND Methods}

A cross-sectional study was conducted among antenatal mothers who visited antenatal clinic at Universiti Kebangsaan Malaysia Medical Centre (UKMMC) from $1^{\text {st }}$ until $19^{\text {th }}$ of August 2016. Respondents who fulfilled the study criteria were selected by using simple random sampling method. The inclusion criteria of this study include being Malaysian citizen and had experience at least once with public healthcare services for antenatal, intrapartum, and postnatal care. The sample size was calculated using formula adhere to the guideline and a minimum sample size of 246 respondents were required to conduct the study (Lwanga \& Lemeshow 1991). However, the targeted sample size was not able to achieve as many respondents were reluctant to participate in the study.

Data was collected using structured questionnaires to assess the opinion of unassisted childbirth without the assistance of medical personnel, demographic and socioeconomic status, health profile, opinion on planned homebirth delivery, quality of government healthcare services and knowledge on unassisted childbirth.

The primary outcome of this study was the opinion of antenatal mothers on unassisted childbirth. This was defined as planning to have a home childbirth or delivery of a new-born at home without the assistance from midwives, doctors, or any healthcare personnel throughout the delivery process. Respondents' opinions on unassisted childbirth were categorized into agree and disagree. Independent variables included demographic and socioeconomic status, health profile, quality of government healthcare services and knowledge on unassisted childbirth.

Health profile of the respondents includes the history of medical illness and current obstetric problems. Respondents with no known medical illness before pregnancy were categorized under 'No' whereas respondents who had history of medical illness before pregnancy were categorized under 'Yes'. Respondents with no health problems developed in current pregnancy were categorized under 'No' whereas respondents who had medical illness developed in current pregnancy were categorized under 'Yes'.

For assessing the data on quality of public healthcare services, factors such as facilities and systems available in public clinics and public hospitals were included. They were further divided into antenatal, intrapartum, and postpartum services provided by the public healthcare settings which include follow-ups, admission, delivery process, and postpartum care. Respondents were required to choose either they were satisfied or dissatisfied with the statements given pertaining to the quality of the facilities 
or services. The maximum score for all the statements was 84. The quality of government healthcare services was assessed by calculating the score of the respondents for all services provided.

As for the respondents' knowledge variable, a set of statements regarding the knowledge on unassisted childbirth were required to be answered. This variable was measured based on the scores obtained by answering the questionnaire whether they agree or disagree with the statements given. The maximum score for all the statements in this section was 24. Knowledge of respondents on planned homebirth delivery was determined by calculating the overall score for all the statements.

All the collected data were analysed using SPSS statistical software package version 20.0 (SPSS, I.I.B.M. 2011). Categorical data such as demographic and socioeconomic status, health profile and opinion on unassisted childbirth were expressed in percentage. The categorical independent variables were tested using Pearson's Chi-squared test and binary logistic regression. The confidence interval was set at $95 \%$ and $p$-value of less than 0.05 was considered as significant level. Numerical data such as quality of government healthcare services and knowledge on unassisted childbirth were described using mean and standard deviation. The association between both the numerical independent variables and opinion on unassisted childbirth were analysed by using independent t-test.

\section{ETHICAL ISSUES}

The ethical approval for this study was obtained from Research Ethics Committee, Medical Faculty Universiti Kebangsaan Malaysia Medical Centre (UKMMC) (Ethic Code: FF-2016-268). All the questionnaires were administered after obtaining the written consent from the respondents to assure the confidentiality of the study and the respondents.

\section{RESULTS}

In this study, a total of 229 respondents who fulfilled the criteria were included in the analysis. Socio-demographic characteristics of the respondents were summarised in Table 1. The majority of the respondents were more than 25 years old $(98.7 \%)$ and among them, majority were Malay (87.3\%). About three quarter of them had high educational level $(76.0 \%)$ and $82.5 \%$ were working mothers. Majority of the antenatal mothers were categorized as middle monthly income and high monthly income with $42.4 \%$ and $42.8 \%$, respectively.
Table 2 summarised the medical history of the respondents. Majority of the respondents $(90.4 \%)$ were not suffering from any medical illness. Moreover, less than one third of the antenatal mothers had past obstetric problems $(27.5 \%)$ whereas $23.6 \%$ of the respondents were experiencing current obstetric problems.

Table 3 summarised the respondents' opinions on unassisted childbirth characterised by demographic and socioeconomic profile. The proportion of respondents with the opinion of agreeable to unassisted childbirth was found to be only $6.6 \%$ among mothers aged more than 25 years old. Besides, majority of the respondents supporting unassisted childbirth belong to the group had high educational level (6.3\%), high monthly household income $(9.2 \%)$ and not working $(20.0 \%)$. Bivariate analysis showed that there was a significant association between the respondents' opinion on unassisted childbirth and their ethnicities $(\mathrm{p}<0.05)$. Malay respondents who agreed with unassisted childbirth were only $5 \%$ whereas the percentage of agreeing to unassisted childbirth was double in non-Malays (17.2\%). Moreover, the respondents' occupational status showed significant association with the opinion on unassisted childbirth whereby $20 \%$ of the respondents who were not working have agreed with unassisted childbirth.

Factors associated with the opinion of antenatal mothers on unassisted childbirth were summarized in Table 4. The result shows that only the middle income group and non-working women were found to be the significant determinants of the opinion on unassisted childbirth in this study $(\mathrm{p}<0.05)$. Middle income group has 15 times odds (95\% $\mathrm{Cl} 1.29-187.94)$ of agreeing to the planned home birth compared to the lower and higher income. Meanwhile, non-working mothers were 19 times more likely (95\% 4.90-77.34) agree to the have delivery at home compared to the working mothers.

Table 5 shows the significant relationship between opinion on unassisted childbirth and the level of satisfaction on the quality of government healthcare services as well as the level of mothers' knowledge on unassisted childbirth. Results showed that mothers who agreed with unassisted childbirth $(n=15)$ had lower satisfaction towards the government healthcare services with a total mean score of 72.4 compared to the mothers who disagreed with unassisted childbirth $(n=214)$ with a total mean score of 73.15. On the other hand, mothers who agreed with unassisted childbirth had also a higher knowledge level (mean score $=21.3$ ) compared to the mothers who disagreed with unassisted childbirth (mean score $=20.87$ ). 
TABLE 1. Demographic and socioeconomic profile of respondents $(\mathrm{N}=229)$

\begin{tabular}{|c|c|c|}
\hline Variable & Frequency, (n) & Percentage, $(\%)$ \\
\hline \multicolumn{3}{|l|}{ Age } \\
\hline$\leq 25$ years old & 3 & 1.3 \\
\hline$>25$ years old & 226 & 98.7 \\
\hline \multicolumn{3}{|l|}{ Ethnicity } \\
\hline Malay & 200 & 87.3 \\
\hline Non Malay & 29 & 12.7 \\
\hline \multicolumn{3}{|c|}{ Husband's educational level } \\
\hline High educational level & 142 & 62.0 \\
\hline Low educational level & 87 & 38.0 \\
\hline \multicolumn{3}{|c|}{ Respondent's educational level } \\
\hline High educational level & 174 & 76.0 \\
\hline Low educational level & 55 & 24.0 \\
\hline \multicolumn{3}{|l|}{ Total Monthly income } \\
\hline Low income & 34 & 14.8 \\
\hline Middle income & 97 & 42.4 \\
\hline High income & 98 & 42.8 \\
\hline \multicolumn{3}{|c|}{ Husband's occupational status } \\
\hline Working & 229 & 100.0 \\
\hline Not working & 0 & 0 \\
\hline \multicolumn{3}{|c|}{ Respondent's occupational status } \\
\hline Working & 189 & 82.5 \\
\hline Not working & 40 & 17.5 \\
\hline
\end{tabular}

TABLE 2. Medical history of respondents $(\mathrm{N}=229)$

\begin{tabular}{lcc}
\hline Medical illness & & \\
\hline Yes & 22 & 9.6 \\
No & 207 & 90.4 \\
Current obstetric problem & & \\
Yes & 54 & 23.6 \\
No & 175 & 76.4 \\
Past obstetric problem & & \\
Yes & 63 & 27.5 \\
No & 166 & 72.5 \\
\hline
\end{tabular}


TABLE 3. Respondents' opinions on unassisted childbirth characterized by demographic and socioeconomic profile (values with * indicates $\mathrm{p}<0.05$ and significant)

\begin{tabular}{|c|c|c|c|c|}
\hline \multirow[b]{2}{*}{ Variable } & \multicolumn{2}{|c|}{ Opinion on unassisted childbirth } & \multirow[b]{2}{*}{$\mathrm{X}^{2}$} & \multirow[t]{2}{*}{$\mathrm{p}$ value } \\
\hline & Agree n (\%) & $\begin{array}{c}\text { Disagree } \\
\mathrm{n}(\%)\end{array}$ & & \\
\hline \multicolumn{5}{|l|}{ Age } \\
\hline$\leq 25$ years old & $0(0.0)$ & $3(100.0)$ & \multirow[t]{2}{*}{0.213} & \multirow[t]{2}{*}{0.644} \\
\hline$>25$ years old & $15(6.6)$ & $211(93.4)$ & & \\
\hline \multicolumn{5}{|l|}{ Race } \\
\hline Malay & $10(5.0)$ & $190(95.0)$ & \multirow[t]{2}{*}{6.200} & \multirow[t]{2}{*}{$0.013^{*}$} \\
\hline Non-Malay & $5(17.2)$ & $24(82.8)$ & & \\
\hline \multicolumn{5}{|l|}{ Husband's Educational level } \\
\hline High educational level & $11(7.7)$ & 131(92.3) & \multirow[t]{2}{*}{0.874} & \multirow[t]{2}{*}{0.350} \\
\hline Low educational level & $4(4.6)$ & $83(95.4)$ & & \\
\hline \multicolumn{5}{|l|}{ Respondent's Educational level } \\
\hline High educational level & $11(6.3)$ & $163(93.7)$ & \multirow{2}{*}{0.062} & \multirow{2}{*}{0.804} \\
\hline Low educational level & $4(7.3)$ & $51(92.7)$ & & \\
\hline \multicolumn{5}{|l|}{ Monthly income } \\
\hline Low income & $1(2.9)$ & $33(97.1)$ & \multirow[b]{3}{*}{2.142} & \multirow[b]{3}{*}{0.343} \\
\hline Middle income & $5(5.2)$ & $92(94.8)$ & & \\
\hline High income & $9(9.2)$ & $89(90.8)$ & & \\
\hline \multicolumn{5}{|l|}{ Husband's Occupational status } \\
\hline Working & $15(6.6)$ & $214(93.4)$ & & \\
\hline Not working & $0(0.0)$ & $0(0.0)$ & & \\
\hline \multicolumn{5}{|c|}{ Respondent's Occupational status } \\
\hline Working & $7(3.7)$ & $182(96.3)$ & 14.323 & $0.001 *$ \\
\hline Not working & $8(20.0)$ & $32(80.0)$ & & \\
\hline \multicolumn{5}{|l|}{ Medical illness } \\
\hline Yes & $0(0.0)$ & $22(100.0)$ & 1.706 & 0.192 \\
\hline No & $15(7.2)$ & $192(92.8)$ & & \\
\hline \multicolumn{5}{|l|}{ Current obstetric problem } \\
\hline Yes & $3(5.6)$ & $51(94.4)$ & 0.114 & 0.735 \\
\hline No & $12(6.9)$ & $163(93.1)$ & & \\
\hline \multicolumn{5}{|l|}{ Past obstetric problem } \\
\hline Yes & $6(9.5)$ & $57(90.5)$ & 1.255 & 0.263 \\
\hline No & $9(5.4)$ & $157(94.6)$ & & \\
\hline
\end{tabular}


TABLE 4. Factors associated with the opinion of antenatal mothers toward unassisted childbirth (values with * indicates $p$ $<0.05$ and significant)

\begin{tabular}{|c|c|c|c|c|c|}
\hline Variables & $\mathrm{SE}$ & Wald Stats & $p$ value & $\begin{array}{l}\text { Odds } \\
\text { Ratio }\end{array}$ & $95 \% \mathrm{CI}$ \\
\hline Low income & & 5.253 & 0.72 & & \\
\hline Middle income & 1.271 & 4.667 & $0.031 *$ & 15.570 & $1.290-187.939$ \\
\hline High income & 0.683 & 2.091 & 0.148 & 2.685 & $0.704-10.244$ \\
\hline Husband Education & 0.873 & 0.744 & 0.388 & 0.471 & $0.085-2.605$ \\
\hline Wife Education & 0.896 & 0.451 & 0.502 & 1.825 & $0.315-10.575$ \\
\hline Non-working mothers & 0.704 & 17.794 & $0.001 *$ & 19.468 & $4.901-77.334$ \\
\hline Current Obs history & 0.731 & 0.016 & 0.899 & 1.097 & $0.262-4.597$ \\
\hline Past Obs History & 0.652 & 2.821 & 0.093 & 0.335 & $0.093-1.201$ \\
\hline
\end{tabular}

TABLE 5. Relationship between opinion on unassisted childbirth with satisfaction on the quality of government healthcare services and knowledge (values with $\mathrm{p}<0.05$ is significant)

\begin{tabular}{cccccc}
\hline Government health care services & Total $(\mathrm{N})$ & Mean & SD & t-stat & p value \\
\hline Agree & 15 & 72.4 & 3.641 & -0.869 & 0.386 \\
Disagree & 214 & 73.15 & 3.202 & & \\
Knowledge on unassisted childbirth & & & & & \\
Agree & 15 & 21.27 & 0.372 & 0.895 & \\
Disagree & 214 & 20.87 & & &
\end{tabular}

\section{DISCUSSION}

Unassisted childbirth is one of the important emerging issues and warranted further attention in the near future. The purpose of this study was to assess the antenatal mothers' opinion on unassisted childbirth and the associated factors influencing their opinions. This study has shown that only minority group of antenatal mothers had agreed on unassisted birth.

Majority of the women who supports unassisted childbirth were Malays and this is consistent with the 
previous findings (Chowdhury et al. 2013; Institute for Public Health, Ministry of Health, Malaysia 2015). The percentage of Malay and non-Malay who agreed with unassisted birth was 10 and 5\%, respectively. Mothers' ethnicity and occupational status were significantly associated with the opinion supporting on unassisted childbirth. Moreover, MLR showed that only middle income and non-working mothers were the significant predictors for this study. To the best of our knowledge, there were no similar study has been conducted to compare the findings of ethnicity and occupational status. However, there were studies reported on the views on childbirth options and associated socio-economic determinants such as the educational and income status (Chowdhury et al. 2013; Shrestha et al. 2012).

One of the determinants for the opinions on unassisted childbirth was found to be the middle household income group. This finding supported the previous study which found that the majority of women who had given birth in hospitals belong to both high and middle income countries (Olsen \& Clausen 2012). The official healthcare system shows that the most cited cases in supporting unassisted childbirth were in Netherlands with approximately $30 \%$ of low risk pregnant women had considered unassisted childbirth at home (Olsen \& Clausen 2012).

In this study, majority of the respondents with high educational level disagreed with unassisted childbirth even though it was not statistically significant. In contrast, previous study had reported that the higher maternal age and educational level of the mother and husband had have influenced on the increase in the number of birth centre usage among women (Pomeroy et al. 2014). Higher maternal educational level has also increased the frequency of antenatal check-up utilisation and was consistent with the previous studies in developing country settings. Nevertheless, a study conducted in Finland had shown that well educated women were less likely would lead to underutilization of birth centres (Chowdhury et al. 2013).

Studies in developing countries showed that richer women were much more likely to give birth in a public facility (Montagu et al. 2011). This was supported by a study in Ghana which reported that women in higher socio-economic strata had greater likelihood of giving birth in health facilities compared to their counterparts (Mrisho et al. 2007). In addition, another study has also found that the household that could afford more, preferred to use the delivery services at hospital instead of homebirth (Pomeroy et al. 2014).
Current finding in relation to the health status in this study contradicted with the previous finding which shows that $3.6 \%$ of respondents who intended for homebirth were known to have medical problems (Meaney et al. 2015). Nevertheless, there was no significant association found between childbirth option and present current obstetric problem status as well as having no-comorbidity. Only small proportion from these categories had agreed with unassisted childbirth. This finding might be due to the higher level of awareness on risks and complications associated with unassisted childbirth among the antenatal mothers, therefore remain disagreeing with planned homebirth.

In our study, the quality of the government healthcare services was not a significant factor in contributing to the opinion on unassisted childbirth. This contradicted with a study which reported that the quality of services provided could influence women's choices on selecting the delivery location (Kumbani et al. 2013). Previous study has also suggested that the women encountered with several barriers such as socio-cultural factors, perceived benefits, economic accessibility and physical accessibility during accessing a skilled attendance for a safe delivery (Kumbani et al. 2013). Additionally, it was shown that the mothers in their first birth, wealthy, living in urban areas, well-educated and aged more than 20 years would prefer a birth facility rather than at home as their priority place of delivery. Higher frequency of antenatal visits aids them in choosing the birth centre for their delivery. This result might be the direct effects from the health education and counselling provided during the antenatal visits in which would have created greater health awareness and comfort on healthcare delivery services among the pregnant mothers (Hasyimah et al. 2014; Pomeroy et al. 2014).

Looking into the satisfaction aspect, this study has found that only minority of the respondents had lower satisfaction towards the quality of government healthcare services. This group might have had poor personal experience in public healthcare settings. This includes conduct of delivery by male doctor, poor communication during labour, did not receive an epidural for painkiller and complications during intrapartum secondary to instrumental delivery. A study in Australia has reason out women's preference in choosing unassisted childbirth such that they were traumatized by the bad experience especially with the attitude and behaviours of the healthcare personnel (Keedle et al. 2013). In this study, the mean score difference between mothers who agreed and disagreed with unassisted childbirth was very minimal. In general, the respondents were satisfied with the current government healthcare services. 
Finally, the relationship between opinions on unassisted childbirth and respondents' knowledge level, shows that the group supporting unassisted childbirth had higher mean score value on knowledge compared to the opposing group. Similar finding was found by another study which showed that the women who goes for homebirth had a thorough understanding and planning on unassisted childbirth (Lothian 2010). Thus, higher knowledge among the respondents in the current study could have built a higher confidence in them to further proceed with unassisted childbirth. Those mothers have better understanding towards the delivery process, risks and complications in unassisted childbirth and they were able to anticipate the possible emergency situations that may happen during the delivery process.

The findings in this study was limited due to the small sample size used following the respondents' reluctant to participate in this study. Besides the respondent's health and mood also influenced their responses to the questionnaire which could have affect the outcome of this study. Other than that, this study has also shared a similar limitation as other cross sectional design on the causality. Despite the limitation, this study is beneficial in providing a better knowledge for the mothers who opt for unassisted childbirth specifically with regards to ethnicity and occupational status in which still remains unexplored.

\section{CONCLUSION}

In conclusion, most of the respondents have disagreed with unassisted childbirth except for mothers that belongs to the middle-income group and non-working groups. Generally, quality of government healthcare services did not influence the respondents' opinion on unassisted childbirth. Meanwhile, conducting current study at the community level with a larger sample size could aid in validating the current findings in which has claimed that the opinion on unassisted childbirth were influenced by mothers' income and occupational status.

\section{REFERENCES}

ACOG Committee on Obstetric Practice, 2011. ACOG Committee Opinion No. 476: Planned home birth. Obstetrics and Gynecology 117(2 Pt 1): 425.

Aliyev, N., Roldan, C. \& Cakmak, B. 2017. The rising home birth trend in America. International Journal of Reproduction, Contraception, Obstetrics and Gynecology 4(6): 16691671.

Chowdhury, M.A.H., Hasan, M.M., Ahmed, S., Darwin, C., Hasan, M.S. \& Haque, M.R. 2013. Socio-demographic factors associated with home delivery assisted by untrained traditional birth attendant in rural Bangladesh. American Journal of Health Research 1(8): 226-230.
Family Health Development Division. 2013. Garis Panduan Pusat Bersalin Alternatif $(A B C)$ di Klinik Kesihatan Malaysia. Ministry of Health. http://www.jknselangor.moh. gov.my/documents/pdf/2016/garis_panduan/kesihatan_ibu/ arartic7.pdf. Accessed on 11 July 2018.

Hasyimah, R., Ismail, A., Jamil, A.T., Jamsiah, M. \& Aizuddin, A.N. 2014. Factors affecting outpatients' satisfaction at Universiti Kebangsaan Malaysia Medical Centre (UKMMC). Malaysian Journal of Public Health Medicine 14(2): 77-85.

Institute for Public Health, Ministry of Health, Malaysia. 2015. The National Health and Morbidity Survey: Maternal and Child Health (MCH). http://www.moh.gov.my/moh/ resources/nhmsreport2015vol2.pdf. Accessed on 11 July 2018.

Keedle, H., Schmied, V., Burns, E. \& Dahlen, H.G. 2015. Women's reasons for, and experiences of, choosing a homebirth following a caesarean section. BMC Pregnancy and Childbirth 15: 206.

Kumbani, L., Bjune, G., Chirwa, E. \& Odland, J.Ø. 2013. Why some women fail to give birth at health facilities: A qualitative study of women's perceptions of perinatal care from rural Southern Malawi. Reproductive Health 10(1): 9.

Lothian, J.A. 2010. How do women who plan home birth prepare for childbirth? The Journal of Perinatal Education 19(3): 62-67.

Lwanga, S.K. \& Lemeshow, S. 1991. Sample Size Determination in Health Studies: A Practical Manual. World Health Organization (WHO).

MacDorman, M.F., Mathews, T.J. \& Declercq, E.R. 2014. Trends in Out-of-Hospital Births in the United States, 19902012 (No. 2014). US Department of Health and Human Services, Centers for Disease Control and Prevention, National Center for Health Statistics.

Meaney, S., Sweeney, S. \& Deaney, J. 2013. Planned Home Births in Ireland Annual Report 2012; HSE national home birth service provided by self-employed community midwives. Cork: Health Services Executive.

Montagu, D., Yamey, G., Visconti, A., Harding, A. \& Yoong, J. 2011. Where do poor women in developing countries give birth? A multi-country analysis of demographic and health survey data. PLoS ONE 6(2): e17155.

Mrisho, M., Schellenberg, J.A., Mushi, A.K., Obrist, B., Mshinda, H., Tanner, M. \& Schellenberg, D. 2007. Factors affecting home delivery in rural Tanzania. Tropical Medicine \& International Health 12(7): 862-872.

Olsen, O. \& Clausen, J.A. 2012. Planned hospital birth versus planned home birth. Cochrane Database of Systematic Reviews 9: CD000352.

Pomeroy, A.M., Koblinsky, M. \& Alva, S. 2014. Who gives birth in private facilities in Asia? A look at six countries. Health Policy and Planning 29(suppl_1): i38-i47.

Shrestha, S.K., Banu, B., Khanom, K., Ali, L., Thapa, N., StrayPedersen, B. \& Devkota, B. 2012. Changing trends on the place of delivery: Why do Nepali women give birth at home? Reproductive Health 9(1): 1-8. 
SPSS. I.I.B.M. 2011. IBM SPSS Statistics for Windows, version 20.0. Armonk, New York: IBM Corporation. p. 440.

Wax, J.R., Lucas, F.L., Lamont, M., Pinette, M.G., Cartin, A. \& Blackstone, J. 2010. Maternal and newborn outcomes in planned home birth vs planned hospital births: A metaanalysis. American Journal of Obstetrics and Gynecology 203(3): 243.e1-243.e8.

Yadav, H. 2012. A review of maternal mortality in Malaysia. International e-Journal of Science, Medicine \& Education 6(Suppl 1): S142-S151.

Aniza Ismail*, Nur Farahani Anas, Neo Shun Qin, Najwa Hayati Ab Ghani, Muhammad Amir Ridzwan Mahadi \& Nur IzatulAisyah Zainal Azeman

Department of Community Health, Faculty of Medicine Universiti Kebangsaan Malaysia

Jalan Yaacob Latif, Bandar Tun Razak 56000 Cheras, Kuala Lumpur, Federal Territory

Malaysia
Leny Suzana Suddin

Department of Public Health Medicine, Faculty of Medicine Universiti Teknologi MARA

Jalan Hospital, 47000 Sungai Buloh, Selangor Darul Ehsan Malaysia

Nor Afiah Mohd Zulkefli \& Anisah Baharom

Department of Community Health, Faculty of Medicine \& Health Sciences

Universiti Putra Malaysia

43400 UPM Serdang, Selangor Darul Ehsan

Malaysia

*Corresponding author; email: aniza@ppukm.ukm.edu.my

Received: 23 July 2019

Accepted: 28 September 2020 